\title{
Achang Chinese
}

National Cancer Institute

\section{Source}

National Cancer Institute. Achang Chinese. NCI Thesaurus. Code C158197.

A Chinese person from the Achang ethnic group. 